\author{
Stupnytska T. \\ Ph.D., Associate Professor \\ Department of Accounting and Auditing \\ E-mail: t.stupnitska@gmail.com
}

\author{
Volodina 0. \\ Assistant \\ Department of Foreigh Languages \\ E-mail: completeness7@mail.ru
}

\author{
Martynovska 0. \\ Undergraduate \\ Department of Accounting and Auditing \\ Odessa National Academy of Food Technologies \\ Kanatna str., 112, Odessa, Ukraine, 65039 \\ E-mail: martynovskaya31@gmail.com
}

\title{
THE ANALYSIS OF THEORETICAL APPROACHES CONCERNING DETERMINATION OF MONETARY MEANS ACCORDING TO THE ACCOUNTING STANDARDS
}

The analysis of theoretical approaches concerning determination of "monetary means" concept and their classification in the economic literature and according to the accounting standards, has been considered in the article. Monetary means are the most available assets of the enterprise, which provide its necessary paying capacity, and it causes the necessity to get full information about their movement and balance in the enterprise to increase efficiency of their use and management.

Key words: monetary means, assets, the most available assets, classification of monetary means.

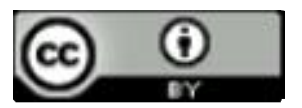

This work is licensed under a Creative Commons Attribution 4.0 International License http://creativecommons.org/licenses/by/4.0/

Statement of the problem and its connection with important scientific and practical tasks. The activity of the enterprise is impossible without using of financial resources. The main place among these resources is occupied by monetary means. Their receipts and use are formed according to the results of economic operations and require target direction, towards achievement of the enterprise tasks concerning its functioning and development . If you don't keep to the order of movement and circulation of monetary means, it will predetermine imbalance of other components of economic means, will result in the enterprise loss of financial independence. Monetary means is one of the important factors, which reveal financial state of the enterprise, its vitality, liquidity and paying capacity. That's why the role of money at the level of the enterprise determines expediency of their meaning and classification research.

The analysis of the latest publications on the problem. The restructuring of the accounting system has been carried on lately in Ukraine. The main task of it is acceleration of conducting of the changes connected with the demands of the international market economy and international accounting standards, which leads to necessity of generalization of the approach to determination of the concept and classification of monetary means. The question of determination of "monetary means" concept and classification of monetary means has been considered national standard of accounting (NSA) 1 ' General demands concerning financial records" and the national standard of accounting 2 "Consolidated financial in the scientific works of such foreign and domestic scientists as Yu. Brigham, L. Gapenski, D.Van Horn, A.King, V.Babich,V.Bocharov, I. Blank, Ph.Butinets, V.Kovalyov, S.Ph.Golov, V.Kostuchenko, A.Zagorodniy, L.Ligonenko, I.Ligonenko, I.Neschodovskiy, G.Osovska, S.Ostaphiychuk, R.Piskunov, A.Poderyogin, S.Sagova, V.Sopko, V.Suchachova, O.Tereshchenko, O.Philimonenko, O.Sheremet and others, but in modern conditions of restructuring of accounting it will require further research.

Forming of the aims of the research. The aim of the article is investigation of determining "monetary means" category and their classification in the economic literature and according to the accounting standards.

Giving an account of the main results and their substantiation. Accounting of monetary means is a regulated normative and lawful act of Ukraine. The accounting order and reflection of monetary means in the financial records are regulated by the Ukrainian Law "About accounting and financial records" and accounting standards. The process of restructuring of the accounting system which is connected with the demands of the international market economy and international accounting standards, is being carried out in Ukraine. One of the main stages of transformation of the accounting records in the country is transition to the international accounting standards. It resulted in introduction of the records", and finally to the structural changes in the forms of the enterprise financial records, which, in its turn, causes necessity of comparison of the approaches 
concerning determination and classification of the enterprise monetary means according to the national and International standards.
Determination of the "monetary means" concept according to International standards and national standards has been given in table 1 .

Table 1

Determination of the "monetary means" concept according to the national and international standards

\begin{tabular}{|l|l|}
\hline \multicolumn{1}{|c|}{ Normative sources } & \multicolumn{1}{|c|}{ Interpretation } \\
\hline $\begin{array}{l}\text { International standard of accounting 7 "Report about } \\
\text { monetary means movement" }\end{array}$ & $\begin{array}{l}\text { Monetary means is a cash in the cash-desk and deposits } \\
\text { on demand. }\end{array}$ \\
\hline $\begin{array}{l}\text { National standards of accounting 1"General requirements } \\
\text { to the yearly financial records" }\end{array}$ & $\begin{array}{l}\text { Ready cash, cash on the bank accounts and deposits on } \\
\text { demand. }\end{array}$ \\
\hline
\end{tabular}

* composed by the authors on the basis of the sources $[1,3]$

From the table 1 we can see, that determination of monetary means according to the national and International standards differs only by presence of monetary means on the bank accounts according to the national standards.

In the economic literature there is no single approach concerning determination of "monetary means" concept.

From the point of view of O.S. Philimonenko, "monetary means - are the means in the form of the mon- ey which is kept in the cash-desk of the enterprise, on the bank accounts, in the letters of credit, on the deposits and which accountable people have [13]. V.I. Yefimenko and L.I. Lukyanenko believe that "monetary means is the cash which is kept at the enterprise, on the bank accounts; bank bills, cheques and transfers of money from the clients" [6]. Theoretical approaches according to the results of the research concerning the essence of "monetary means" category in the economic literature, have been given in table 2 .

Table 2

Approaches concerning the essence of "monetary means" concept in the economic literature*

\begin{tabular}{|c|c|}
\hline Author & Interpretation \\
\hline S.M. Ostafiychuk & $\begin{array}{l}\text { Monetary means are absolutely available assets, that's why, one can't refer absolutely } \\
\text { all balances on the bank accounts to this concept, because their liquidity can be greatly } \\
\text { different from the absolute one. }\end{array}$ \\
\hline $\begin{array}{l}\text { Yi.S. Zavadskiy } \\
\text { G.V. Osovska }\end{array}$ & $\begin{array}{l}\text { Monetary means can be presented not only in the form of incomes and earnings, that } \\
\text { are accumulated in the form of money on the accounts of the enterprise, organization, } \\
\text { institution in the banks and are used to provide their own needs or to allocate in the } \\
\text { form of the bank resources and in the form of expenses. }\end{array}$ \\
\hline $\begin{array}{l}\text { V.V. Babich } \\
\text { S.V. Sagova }\end{array}$ & Monetary means is the currency of Ukraine and foreign currency. \\
\hline I.S. Neschodovskiy & $\begin{array}{l}\text { Monetary means is an abstract measure of the economic processes, phenomena, ob- } \\
\text { jects, which the subjects agree to accept as a method of payment. }\end{array}$ \\
\hline Ph.Ph. Butinets & $\begin{array}{l}\text { Monetary means is a form of money existence, are used as a way of payment, paper } \\
\text { currency of the national currency of Ukraine banknotes and coins, including memora- } \\
\text { ble and jubilee coins, which are in the circulation and are real means. }\end{array}$ \\
\hline O.S. Vysochan & $\begin{array}{l}\text { Monetary means are cash in the cash-desk, electronic money, money on the current and } \\
\text { other accounts in the banks, which can be used at any moment to carry out calculations } \\
\text { in the process of performing the economic operations. }\end{array}$ \\
\hline N.M. Tkachenko & Monetary means is a cash balance, cash on the bank account, other money means. \\
\hline I. Blank & $\begin{array}{l}\text { Monetary means is a totality of incomes divided by the intervals of time and payouts of } \\
\text { monetary means, which are generated by its economic activity, the movement of which } \\
\text { is connected with factors of time, risk and liquidity. }\end{array}$ \\
\hline
\end{tabular}

*composed by the authors on the basis of the sources $[5,7,10,12]$

The analysis of determination of "monetary means" concept according to the economic and accounting standards testifies that in spite of its wide-spread theoretic use and practical application, there is no single approach to the interpretation of this concept.

We share the opinion with the scientists who agree with the determination, given in NSA 1, who be- lieve that "monetary means are the most available assets of the enterprise, which can be in the form of ready cash, cash on the bank accounts, deposits on demand"[1,16,13]. This determination generalizes approaches to determination of monetary means and contains: essence of monetary means, direction of their application and the final result. 
The efficient management, qualitative accountings and analysis of monetary means cause the necessity of learning the classification of monetary means by different features. The classification of monetary means is an important element for organization of their accounting, because it allows to structure them according to the information demands of the customers [4]. Theoretical approaches to the classification of monetary means, which are the most wide-spread in the economic literature, have been systematized in table 3 .

Table 3

Approaches to the classification of monetary means in the economic literature*

\begin{tabular}{|c|c|}
\hline Classification feature & Composition of monetary means \\
\hline By types of currency & $\begin{array}{l}\text { - in the national currency } \\
\text { - in the foreign currency }\end{array}$ \\
\hline By natural form & $\begin{array}{l}\text { - ready cash } \\
\text { - cashless monetary means }\end{array}$ \\
\hline By the place of keeping & $\begin{array}{l}\text { - monetary means in the bank account } \\
\text { - monetary means in the cash-desk } \\
\text { - equivalents of monetary means } \\
\text { - accountable cash } \\
\text { - paid out advances }\end{array}$ \\
\hline By purpose & $\begin{array}{l}\text { - circulating } \\
\text { - non-circulating } \\
\text { - of special purpose }\end{array}$ \\
\hline $\begin{array}{l}\text { Depends on the account, on which } \\
\text { they are reflected }\end{array}$ & $\begin{array}{l}\text { - in the cash-desk } \\
\text { - on the current accounts } \\
\text { - in the currency market } \\
\text { - which accountable people have }\end{array}$ \\
\hline By the degree of business activity & $\begin{array}{l}\text { - active } \\
\text { - passive }\end{array}$ \\
\hline By the sources of receipts & $\begin{array}{l}\text { - personal } \\
\text { - attracted } \\
\text { - borrowed }\end{array}$ \\
\hline $\begin{array}{l}\text { By the approach to determination } \\
\text { of monetary means volume }\end{array}$ & $\begin{array}{l}\text { - in the broad sense - as monetary means, advanced in the enterprise property } \\
\text { - in the narrow sense - as part of current assets, which is directly in the money } \\
\text { form }\end{array}$ \\
\hline By functional purpose & - as a stock of cash, created with a certain purpose \\
\hline $\begin{array}{l}\text { By limitation in the directions } \\
\text { of application }\end{array}$ & $\begin{array}{l}\text { - limited in application (monetary means, which the enterprise can use strictly } \\
\text { according to the certain purpose) } \\
\text { - unlimited in application (monetary means, which the enterprise can deal } \\
\text { without any restrictions for carrying out the economic activity) }\end{array}$ \\
\hline
\end{tabular}

*composed by the authors on the basis of the sources [8-11]

In our opinion, it's not expedient to refer the cash, which is given on account or advances, to the monetary means, because they are elements of debts receivable.

In the practice the monetary means accounting is regulated normative and lawful documents of Ukraine. The order of reflecting the monetary means in the financial records is regulated by the National standard of Accordind1 "general requirements to the financial records." Norms of this standards are used to the financial records and consolidated financial records of juridical people of all forms of properties (except banks and budget enterprises), which have to produce financial records according to the legislation [1]. Monetary means are the most available assets of the enterprise, which provide its necessary paying capacity, which causes the necessity of obtaining full information about their movement and balances at the enterprise and it makes consideration of the classification of monetary means necessary according to the forms of the enterprise financial records.

The information about monetary means is reflected in the following forms of financial records:

- form №1 "Balance (Records about the financial state);

- form №3 "Records about monetary means movement"; records".

- form №5 "Notes to the yearly financial

The classification of monetary means by the forms of the financial records of the enterprise according to the national standards of accounting has been given in table 4.

According to the international accounting standards, monetary means are classified analogically, but with less details. 
Table 4

Classification of monetary means by the forms of the financial records of the enterprise according to the national standards of accounting*

\begin{tabular}{|l|c|l|}
\hline Forms of financial records which reflect the monetary means & $\begin{array}{c}\text { Code of the } \\
\text { line }\end{array}$ & \multicolumn{1}{|c|}{ The title of the article } \\
\hline \multirow{3}{*}{ Form №1 "Balance (Records about the financial state) " } & 1165 & Money and its equivalents, including: \\
\cline { 2 - 3 } & 1166 & Ready cash \\
\hline \multirow{3}{*}{$\begin{array}{l}\text { Form №3 "Records about monetary means movement" (by } \\
\text { the direct method) }\end{array}$} & 3405 & $\begin{array}{l}\text { Balance of the cash by the beginning } \\
\text { of the year }\end{array}$ \\
\cline { 2 - 3 } & 3410 & $\begin{array}{l}\text { Influence of currencies change in the } \\
\text { balance }\end{array}$ \\
\cline { 2 - 3 } & 3415 & $\begin{array}{l}\text { Balance of the cash by the end of the } \\
\text { year }\end{array}$ \\
\hline \multirow{3}{*}{ Form №5 "Notes to the yearly financial records" } & 640 & Ready cash \\
\cline { 2 - 3 } & 650 & Current bank account \\
\cline { 2 - 3 } & 660 & Other bank account \\
\cline { 2 - 3 } & 670 & Monetary means on the way \\
\cline { 2 - 3 } & 680 & Equivalents of monetary means \\
\hline
\end{tabular}

*composed by the authors on the basis of the sources $[1,3]$

So, according to the form of the financial records "Records about the financial state" the information about monetary means and their equivalents as a whole is revealed and in the notes the information about the policy, which the business unit accepts for determination of monetary means composition and their equivalents, which is stipulated by differences in monetary means management in the whole world, is revealed [2].

Conclusions and prospects of the further investigations. The analysis of "monetary means" concept and monetary means classification in the economic literature and accounting standards has allowed to consider the essence of "monetary means" concept and to systematize their classification. The conducted research testifies that nowadays the common approach to determination of the essence of "monetary means" concept and their classification is absent. Transition of Ukraine to the international standards leads to necessity of having the common approach to determination of the concept and classification of monetary means.

\section{References}

1. Natsionalne polozhennia (standart) bukhhalterskoho obliku 1 «Zahalni vymohy do finansovoi zvitnosti» zatverdzhene nakazom Ministerstva finansiv 07.02.13 №73): za stanom na 8 liutoho 2014 r. (2014). Retrieved from https://buhgalter911.com/uk/normativnaya-baza/instr-plan-rah/standart-buhgalterskogo/nacionalyne-pologhennyastandartu-1021081.html

2. MSBO 1 «Podannia finansovoi zvitnosti». (2015). Retrieved from https://buhgalter911.com/public/uploads/msfo/MSBO1_01012015.pdf

3. MSBO 7 «Zvit pro rukh hroshovykh koshtiv». (2015). Retrieved from https://buhgalter911.com/public/uploads/msfo/MSBO7 01012015.pdf

4. Forma № 5 «Prymitky do richnoi finansovoi zvitnosti» (zatverdzheno nakazom Minfinu vid 29.11.2000 №302 u redaktsii nakazu Minfinu vid 28.10.2003 №602 iz zminamy vnesenymy nakazamy Minfinu №989 vid 10.12.2002, №602 vid 28.10.2003, №1238 vid 14.10.2008. (2008). Retrieved from https://buhgalter911.com/blanki/finansovaya-otchetnost/forma-n-5-prymitki

5. Bondarenko, N. M., \& Taran, V. V. (2017). Orhanizatsiia obliku i kontroliu hroshovykh koshtiv. Prychornomorski ekonomichni studii, (17), 229-234. KNEU.

6. Iefimenko, V. I., \& Luk'ianenko, L. I. (2005). Oblik u zarubizhnykh krainakh (V. I. Iefimenko, Ed.). K.:

7. Ivchenko, L. V. (2016). Sutnist hroshovykh koshtiv: pidkhody do vyznachennia. Retrieved from http://global-national.in.ua/archive/10-2016/167.pdf

8. Ostafiichuk, S. M. (2011). Klasyfikatsiia hroshovykh koshtiv ta yikh ekvivalentiv dlia potreb bukhhalterskoho obliku ta analizu. Naukovi pratsi Kirovohradskoho natsionalnoho tekhnichnoho universytetu. Ekonomichni nauky., (20), II, 261-267

9. Sopko, V. (2010). Bukhhalterskyi oblik (2 vyd., pererob. i dop. ed.). K.: KNEU.

10. Pyskunov, R. A., \& Sukhacheva, V. A. (2014). Klasyfikatsiia hroshovykh koshtiv. Retrieved from http://nauka.kushnir.mk.ua/?p=74812 
11. Poddierohin, A. M., \& Nevmerzhytskyi, Ia. I. (2010). Efektyvnist upravlinnia hroshovymy potkamy pidpryiemstva. Finansy Ukrainy, (11), 119-127.

12. Tkachenko, N. M. (2011). Bukhhalterskyi oblik, opodatkuvannia i zvitnist (5-te vyd. ed.). K.: Altera.

13. Filimonenko, O. S. (2005). Finansy pidpryiemstv. K.: Kondor.

Received 13 October 2017

Approved 29 October 2017

Available in Internet 30.12.2017

Ступницкая Т.M.

кандидат экономических наук, доцент кафедра учета и аудита

E-mail: t.stupnitska@gmail.com

\section{Володина Е.П.}

ассистент

кафедра иностранных языков

E-mail: completeness7@mail.ru

\section{Мартыновская О.C.}

магистрант

кафедра учета и аудита

Одесская национальная академия пищевых технологий

ул. Канатная, 112, г. Одеса, Украина, 65039

E-mail: martynovskaya31@gmail.com

\section{АНАЛИЗ ТЕОРЕТИЧЕСКИХ ПОДХОДОВ К ОПРЕДЕЛЕНИЮ ДЕНЕЖНЫХ СРЕДСТВ ПО СТАНДАРТАМ БУХГАЛТЕРСКОГО УЧЕТА}

Деятельность предприятия недопустима без использования финансовых ресурсов. Главное место среди этих ресурсов занимают денежные средства. Их поступление и расходование формируется по результатам хозяйственных операций и требует целевого направления на достижение предприятием задач его фрункционирования и развития. Денежные средства являются наиболее ликвидными активами предприятия, которая обеспечивает его необходимую платежеспособность, что обуславливает необходимость получения полной информации об их движении и остатках на предприятии для повышения эффективности их использования и управления.

В статье проведен анализ определения категории «денежные средства» и классификации денежных средств в экономической литературе и нормативных источниках. Это позволило рассмотреть сущность понятия «денежные средства» и систематизировать их классификацию. В процессе исследования использовались методы: сравнительного анализа и классификации. Проведенный анализ показал, что на сегодняшний день отсутствует единый подход к определению сущности понятия «денежные средства» и их классификации. Переход Украины на международные стандарты обуславливает необходимость выработки единого подхода к определению понятия и классификации денежных средств. По нашему мнению для целей бухгалтерского учета, а также для обеспечения информационных потребностей пользователей необходимо использовать определение и классификацию денежных средств по нормативно-правовым актам.

Ключевые слова: денежные средства, активы, наиболее ликвидные активы, классификация денежных средств.

Ступницька Т.М.

кандидат економічних наук, доцент кафедра обліку та аудиту

E-mail: t.stupnitska@gmail.com

\section{Володіна О.П.}

асистент

кафедра іноземних мов

E-mail: completeness7@mail.ru

\section{Мартиновська О.С.}

магістрант

кафедра обліку та аудиту

Одеська національна академія харчових технологій вул. Канатна, 112, м. Одеса, Україна, 65039

E-mail: martynovskaya31@gmail.com

\section{АНАЛІЗ ТЕОРЕТИЧНИХ ПІДХОДІВ ЩОДО ВИЗНАЧЕННЯ ГРОШОВИХ КОШТІВ ЗА СТАНДАРТАМИ БУХГАЛТЕРСЬКОГО ОБЛІКУ}

Діяльність підприємства неможлива без використання фінансових ресурсів. Головне місце серед цих ресурсів займають грошові кошти. Їх надходження та витрачання формується за результата- 
ми господарських операцій і вимагає цільового спрямування на досягнення підприємством завдань його функціонування та розвитку. Грошові кошти є найбільш ліквідними активами підприємства, яки забезпечують його необхідну платоспроможність, що викликає необхідність отримання повної інформації про їх рух та залишки на підприємстві для покращення ефективності їх використання та управління.

В статті проведений аналіз поняття «грошові кошти» та класифікації грошових коштів в економічній літературі та за стандартами бухгалтерського обліку. Це дозволило розглянути сутність поняття «грошові кошти» та систематизувати їх класифікацію. В процесі дослідження використовувались методи: порівняльного аналізу та класифікації. Проведений аналіз показав, що на сьогоднішній день відсутній єдиний підхід щодо визначення сутності поняття «грошові кошти» та їх класифікації. Перехід України до міжнародних стандартів призводить до необхідності узагальнення підходу до визначення поняття та класифікації грошових коштів. На нашу думку для цілей бухгалтерського обліку, а також для забезпечення інформаційних потреб користувачів необхідно використовувати визначення та класифрікацію грошових коштів за нормативно-правовими актами.

Ключові слова: грошові кошти, активи, найбільш ліквідні активи, класифікація грошових коштів.

\section{Література}

1. Національне положення (стандарт) бухгалтерського обліку 1 «Загальні вимоги до фінансової звітності» затверджене наказом Міністерства фінансів 07.02.13 №73) : за станом на 8 лютого 2014 р. - [Електронний pecypc]. - Режим доступу: https://buhgalter911.com/uk/normativnaya-baza/instr-plan-rah/standartbuhgalterskogo/nacionalyne-pologhennya-standartu-1021081.html

2. МСБО 1 «Подання фінансової звітності» [Електронний ресурс]. - Режим доступу: https://buhgalter911.com/public/uploads/msfo/MSBO1_01012015.pdf

3. МСБО 7 «Звіт про рух грошових коштів» [Електронний ресурс]. - Режим доступу: https://buhgalter911.com/public/uploads/msfo/MSBO7 01012015.pdf

4. Форма № 5 «Примітки до річної фінансової звітності» (затверджено наказом Мінфіну від 29.11.2000 №302 у редакції наказу Мінфіну від 28.10.2003 №602 із змінами внесеними наказами Мінфіну №989 від 10.12.2002, №602 від 28.10.2003, №1238 від 14.10.2008. - [Електронний ресурс]. - Режим доступу: https://buhgalter911.com/blanki/finansovaya-otchetnost/forma-n-5-prymitki/.

5. Бондаренко Н.М. Організація обліку і контролю грошових коштів / Н.М.Бондаренко, Таран В.В. // Причорноморські економічні студії. - 2017. - Вип.17. - С.229-234

6. Єфіменко В.І. Облік у зарубіжних країнах: [навч.-метод. посіб. для самост. вивч. дисц.] / В.І. Єфіменко, Л.І. Лук'яненко; за ред. В.І. Єфіменка. - К.: КНЕУ, 2005. -211 с.

7. Івченко Л.В. Сутність грошових коштів: підходи до визначення [Електроний ресурс] / Івченко Л.В. - Режим доступу: http://global-national.in.ua/archive/10-2016/167.pdf

8. Остафійчук С.М. Класифікація грошових коштів та їх еквівалентів для потреб бухгалтерського обліку та аналізу / С.М. Остафійчук // Наукові праці Кіровоградського національного технічного університету. Економічні науки. - 2011. - Вип.20, Ч.ІІ. - С.261-267

9. Сопко В. Бухгалтерський облік: [навчальний посібник] / В. Сопко.- [2 вид., перероб. і доп.] - К.: KНEУ, 2010. -500 c.

10. Пискунов Р.А. Класифікація грошових коштів [Електроний ресурс] / Р.А.Пискунов, В.А.Сухачева. Режим доступу: http://nauka.kushnir.mk.ua/?p=74812

11. Поддерьогін А.М. Ефективність управління грошовими потками підприємства [Текст] / А.М. Поддєрьогін, Я.І. Невмержицький // Фінанси України. - 2010. - № 11. - С. 119-127.

12. Ткаченко Н.М. Бухгалтерський облік, оподаткування і звітність: підруч. / Н.М. Ткаченко. - 5-те вид. - К.: Алтера, 2011. - С. 151.

13. Філімоненко О.С. Фінанси підприємств: [навч. посіб.] / О.С. Філімоненко. - К.: Кондор, 2005. - С. 351.

Стаття надійшла 13.10.2017 Стаття прийнята до друку 29.10.2017 Доступно в мережі Internet 30.12.2017 